\title{
The Design Of Arduino Prototype For Monitoring Septic Tank Using Message Gateway
}

\author{
Setia Susilawati ${ }^{\mathrm{a}, 1, *}$, Sunarsan Sitohang ${ }^{\mathrm{b}, 2}$ \\ ${ }^{\mathrm{ab}}$ Universitas Putera Batam, J1. R. Soeprapto Muka Kuning, Batam 29434, Indonesia \\ ${ }^{1}$ susilawatithya@gmail.com*; ${ }^{2}$ sunarsan@puterabatam.ac.id \\ * corresponding author
}

\begin{tabular}{|c|c|}
\hline & ABSTRACT \\
\hline $\begin{array}{l}\text { Keywords } \\
\text { Arduino } \\
\text { Prototype } \\
\text { Septik tank } \\
\text { Sensor MQ-2 } \\
\text { SIM800L }\end{array}$ & $\begin{array}{l}\text { The housing that is currently being built usually only has a small septic tank, which can } \\
\text { lead to problems with the tank if the tank is full. Starting from the blocked septic tank can } \\
\text { even explode. The purpose of this research is to make prototype in monitoring a tank in a } \\
\text { septic tank with Message Gateway. The tools used in this study are Arduino Uno which is } \\
\text { tntegrated with ultrasonic sensors, MQ- } 2 \text { sensors and SIM800L Modules, after which the } \\
\text { LCD receives data from Arduino and is displayed on the LCD followed by a LED light. } \\
\text { And fro SIM800L it will automatically send a short message. The result of this research if } \\
\text { this study after Arduino processed data from the HC-SR04 Ultrasonic Sensor and MQ- } 2 \\
\text { Sensor then the sensor sent a signal to SIM800L and SIM800L sent a Message to the user } \\
\text { with a warning of } 30 \%, 50 \% \text { and } 100 \% \text { water level septic tank. The MQ- } 2 \text { sensor can only } \\
\text { detect gas in the septic tank, if the gas in the septic tank is more than } 15.000 \text { ppm it will } \\
\text { automatically send a Message to the user that the Danger Gas, which indicates that this } \\
\text { prototype has been running as expected.. }\end{array}$ \\
\hline
\end{tabular}

\section{Introduction}

Wastewater or the term Blackwater is one of the contemporary problems as population density is increasing. In general, every family or who have a place to live must have a waste disposal site or often we say a septic tank. Most of the waste disposal site or often we say a septic tank. Most of the waste dumped in sewers or rivers and there are some of a company has its own disposal site that will be controlled by the septic tank waste management agency. The contents of the contents of the septic tank itself has a composition that is harmful to the community environment. The composition that is harmful to the community environment. The composition of the septic tank waste is $60 \%$ methane gas and 35\% carbon dioxide and the rest is sulfuric acid and ammonia which causes odors in the septic $\operatorname{tank}[1]$

If the gas in the septic tank evaporates to the surface it will cause an explosion, an explosion occurs due to a pile of methane gas, the process of formation of methane gas is called an anaerobic process[2]. In this process there should be no oxygen entering because bacteria can live without oxygen, so why should a septic tank have a certain depth. If the construction of the septic tank does not match its size, the vapor or dirt in the septic tank will evaporate to the surface which can disturb the environment and cause an explosion. For this reason, an Arduino prototype was made in the monitoring design of a septic tan that aims to develop a prototype system for monitoring design of a septic tank that aims to develop a prototype system for monitoring the height of a septic tank with an ultrasonic sensor HCSR04 integrated with Arduino in measuring the height of a septic tank and the MQ-2 sensor can detect gas in the tank septic tank. 


\section{The Proposed Method}

The method in this research is divided into two parts, namely the hardware is used to take a series of components on the equipment to be produced, after that the design of software as a medium in making a program using Arduino Uno.

\subsection{Arduino}

Arduino is an electronic circuit board that is easy to understand, Arduino display is made easy so that people who are new to understanding Arduino in conducting interactive projects easily and in teresting ways [3]. Arduino is usually used to design electronic devices such as robotic control. The programming language used in Arduino is the $\mathrm{C}++$ programming language [4][5].

\subsection{HC-SR04 Ultrasonic Sensor}

HC-SR04 ultrasonic sensor is a non-contact sensor that measures a distance using ultrasonic [3]. This sensor can detect distances ranging from $2 \mathrm{~cm}$ to $4 \mathrm{~m}$. in this sensor has a transmitter, receiver and control circuit.

\subsection{MQ-2 Gas Sensor}

MQ-2 Gas Sensor is a sensor that requires a 5V DC voltage to operate and is sensitive to gas and smoke. The output voltage of this module will be higher when more gas or smoke is detected. Converseky, the output voltage will be lower even undetected when there is less gas and smoke. For the record, the best time to pre-heat the MQ-2 sensor is more than $>24$ hours.

\subsection{SIM800L Module}

This module can function the same as cellular telephone. In Indonesia the SIM800L module can be useful in the business industry because the SIM800L module has Message, Web, Call based function. SIM800L also already has various types for example the adapter version uno.

\subsection{Liquid Crystal Display}

Liquid Crystal Display or better known in robotics is the LCD screen is a display of the results of programming such as Arduino Uno. This module uses a liquid crystal matrix display module with a LCD controller in it. This control has RAM/ROM, character generator that is located inside the module [6][7]. 


\section{Method}

\subsection{Hardware Design}

In hardware design is important because in this design is the stage in the formation of electronic circuits, this design consists of a series of components used. The results of hardware design can be seen in Fig. 1, as follows:

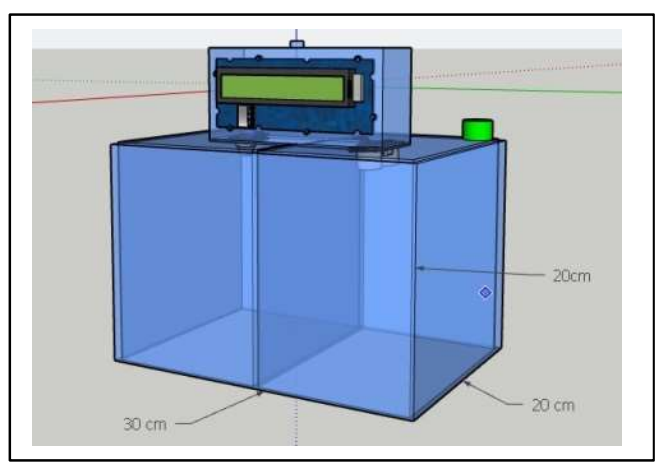

Fig. 1. Hardware Design

\subsection{Electrical Device Design}

On Figure. 2 is a display of the entire electrical device. The control system in monitoring water levels and detecting gas levels in this study, uses electronic components as the main tool in this design and requires an electrical design in order to function optimally. Electronic components used in this design are Arduino Uno, MQ-2 Sensor, Ultrasonic Sensor, 16 x 2 Display with IC, SIM800L. Module and so on. Components connected to the Arduino uno pin also exist in Table 1 where Arduino uno is the center of the devices used, in the table below displays the types of outputs and inputs allocated to the Arduino uno pin.

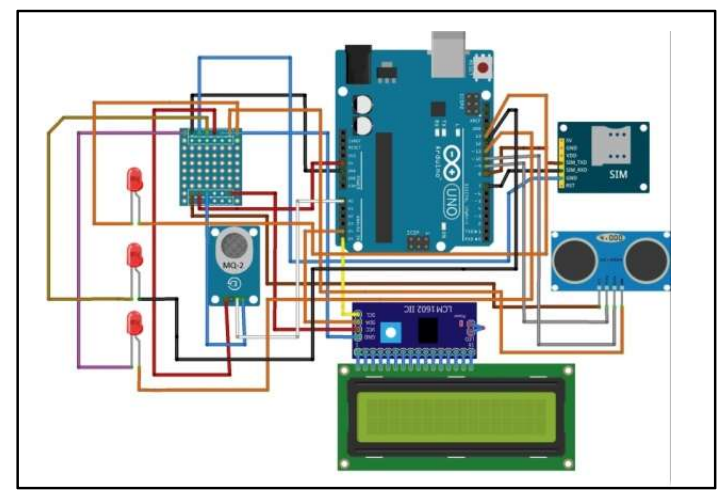

Fig. 2. Electrical Device Design

Table 1. Use of Arduino Uno R3 Pins

\begin{tabular}{lcc}
\hline \multicolumn{1}{c}{ Name I/O } & Type & Arduino Uno R3 Pins Allocation \\
\hline MQ-2 Sensor & Input & $5 \mathrm{~V}, \mathrm{GND}, \mathrm{A} 0$ \\
\hline $\begin{array}{l}\text { Sensor Ultrasonik HC- } \\
\text { SRO4 }\end{array}$ & Input & $5 \mathrm{~V}, \mathrm{D} 10 \mathrm{PWM} / \mathrm{SS}, \mathrm{D} 8, \mathrm{GND}$ \\
\hline Modul SIM800L & Output & GND, D7, D8 \\
\hline I2C & Output & $5 \mathrm{~V}, \mathrm{GND}, \mathrm{A} 4 / \mathrm{SDA}, \mathrm{A} / \mathrm{SCL}$
\end{tabular}




\subsection{Software Design}

On Figure. 3 down below is a flowchart of a program diagram describing software that aims to mnitor a septic tank prototype work system that has been designed in this study. This prototype detects gas levels in the septic tank and the height of the septic tank and provides information via a Message gateway. When a septic tank is filled, both Mq-2 and ultrasonic sensors read the highest gas content and water level. After that Arduino Uno processes the data, the data will be sent via Message to the user and will also appear on the LCD in the series of research tools..

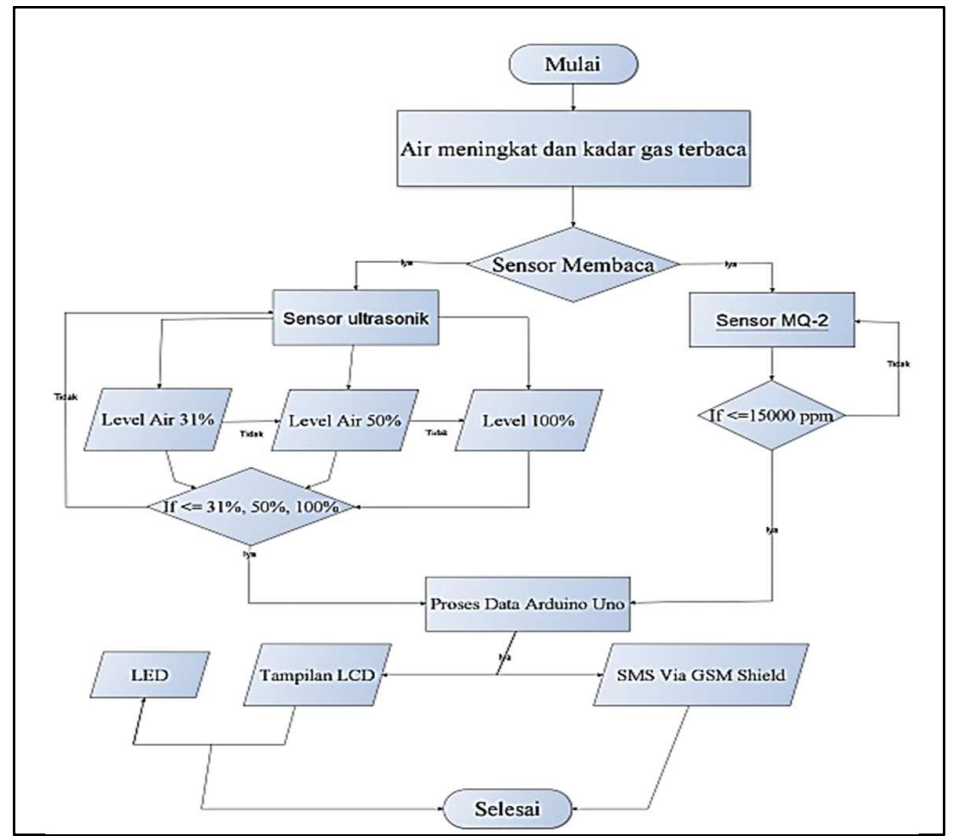

Fig. 3. Software Design

\section{Results and Discussion}

\subsection{Tools Testing}

\section{1. $31 \%$ Success Test}

This test is to ensure the ultrasonic sensor can measure water level $31 \%$, LCD display can display the detected results on the sensor and Message can be sent automatically. Here are the results of the test:

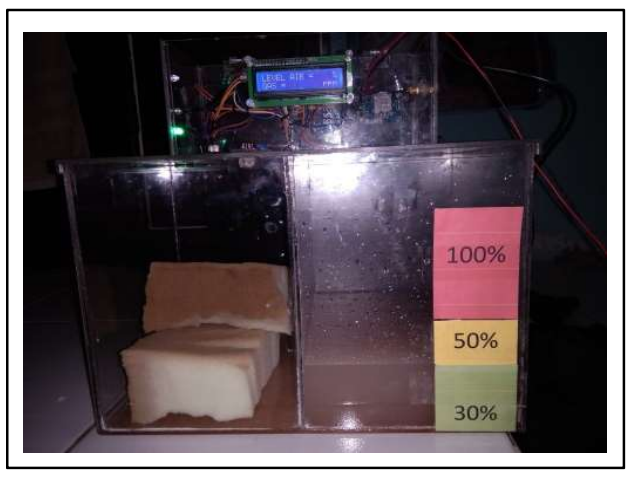

Fig. 4. $31 \%$ Water Level 


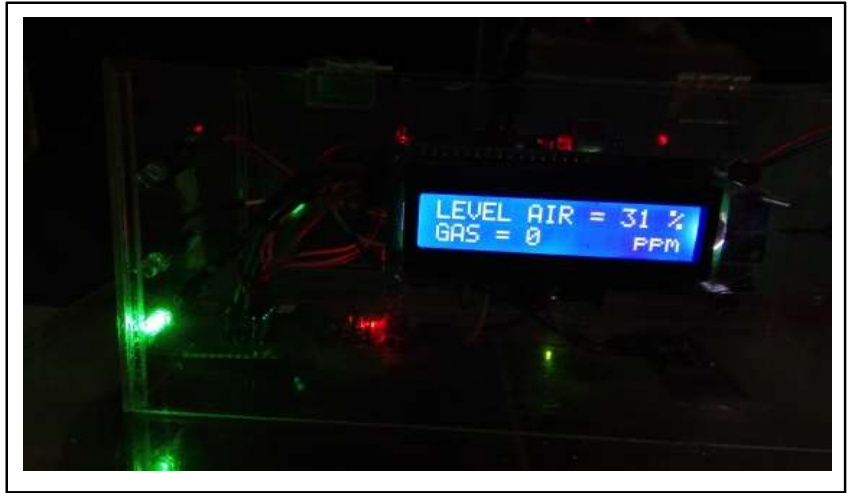

Fig. 5. LCD and LED Display

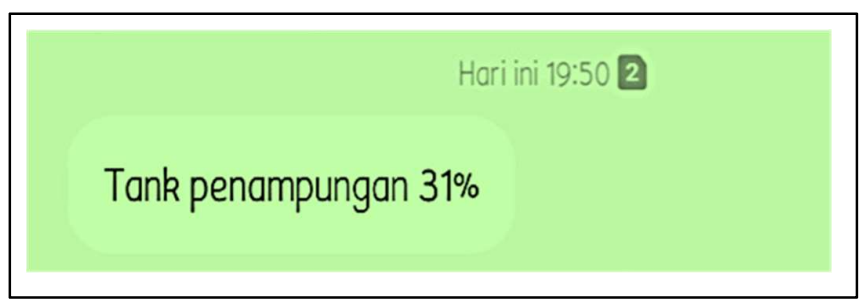

Fig. 6. Message Display

In the Fig. 4 shows that the water level is already at $31 \%$ automatically the results obtained directly appear on the LCD screen, can be seen in Fig. 5 which is the result of an ultrasonic sensor. But at this height no gas is detected, the result of zero gas. After that the notification will automatically enter the user's smartphone in the form of a message that says "Storage Tank 31\%" can be seen in Fig.6. Then the success test of $31 \%$ can run and the results obtained as expected.

\section{2. $50 \%$ Success Test}

This test is carried out to determine the ultrasonic sensor can measure water level $50 \%$, the gas can be detected by using the MQ-2 sensor and the LCD can display the results that have been measured by the ultrasonic sensor after knowing whether the SIM800L module is automatically immediately sent a message. Following are the test results:

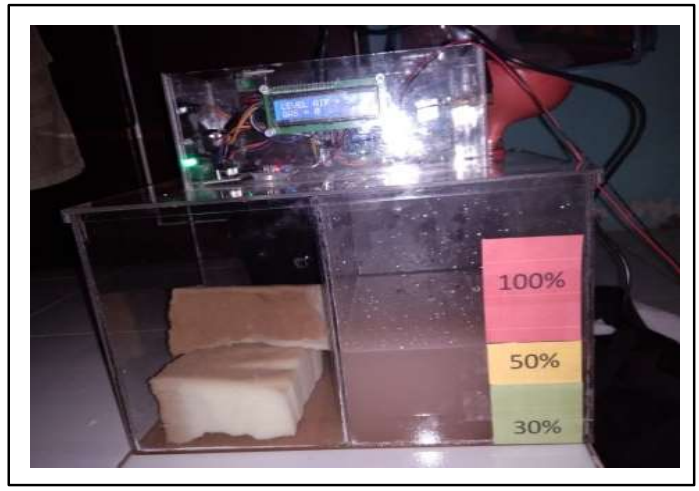

Fig. 7. $50 \%$ Water Level 


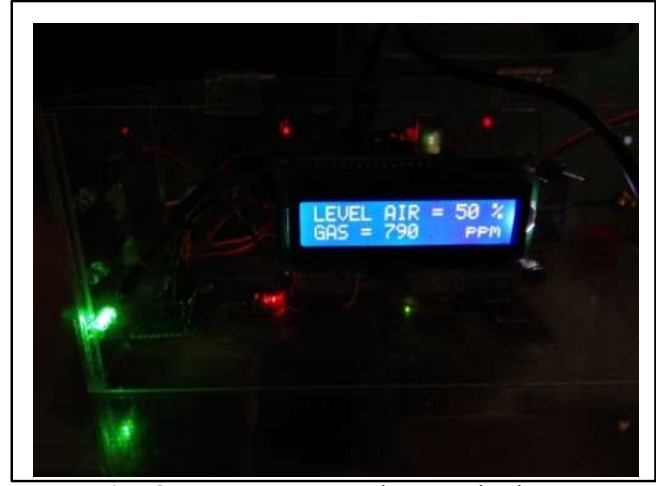

Fig. 8. $\quad$ LCD and Gas Display

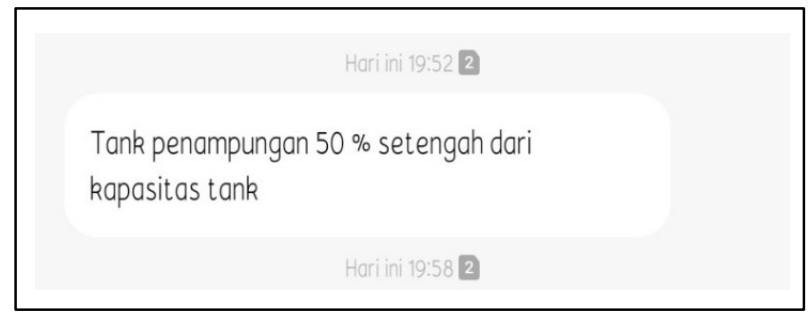

Fig. 9. Message Display

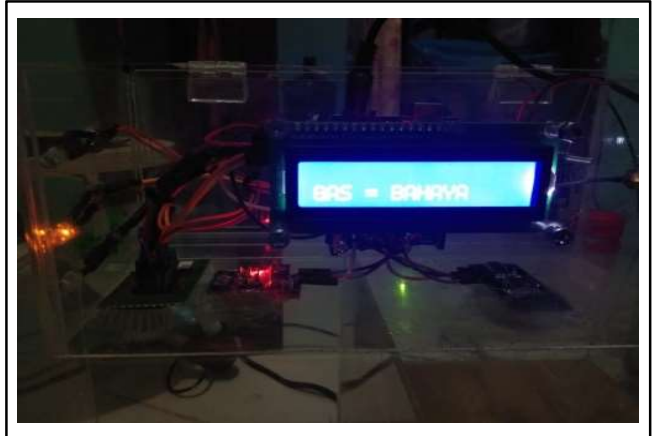

Fig. 10. Hazard Gas LCD Display at Level 50\%

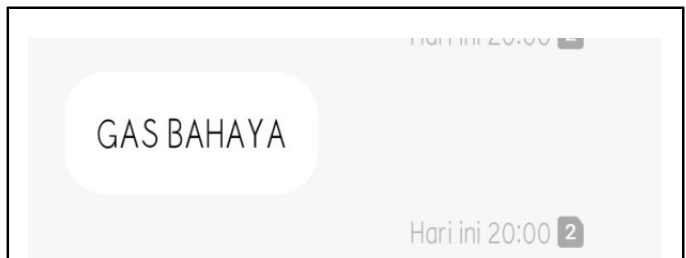

Fig. 11. Display Message 50\% Gas Hazard

In the Fig. 7 shows that the water level is already at 50\% automatically the results obtained directly appear on the LCD screen, can be seen in Fig. 8 which is the measurement result of the ultrasonic sensor. At an altitude of $50 \%$, it turns out that there is a gas content seen in the Fig. 8 gas detected at $790 \mathrm{ppm}$. At an altitude of 50\%, a notification will also enter on the user's smartphone in the form of a message that says "Storage Tank 50\% half of the tank capacity" can be seen in Fig.9. But it could be that at this height the gas turns into dangerous could be because the septic tank is designed too 162 | P a g e 
small and the gas evaporates faster, then the MQ-2 sensor automatically detects dangerous gas or the gas has exceeded 15,000 ppm can be seen in Fig.10 the notification will also enter the smartphone that has been setup, the form of messages sent on the smartphone can be seen in Fig.11. Then the success test results of $50 \%$ can run and the results obtained as expected.

\section{3. $100 \%$ Success Test}

This test is carried out to find out an ultrasonic sensor can measure the water level which has reached $100 \%$, automatically sends a message to the user accompanied by a LCD display of $100 \%$ water level and gas detection value. If the gas in the tank exceeds the limit, it will automatically send a short message "Gas Hazard" and will appear on the LCD Display. Here are the results of the test:

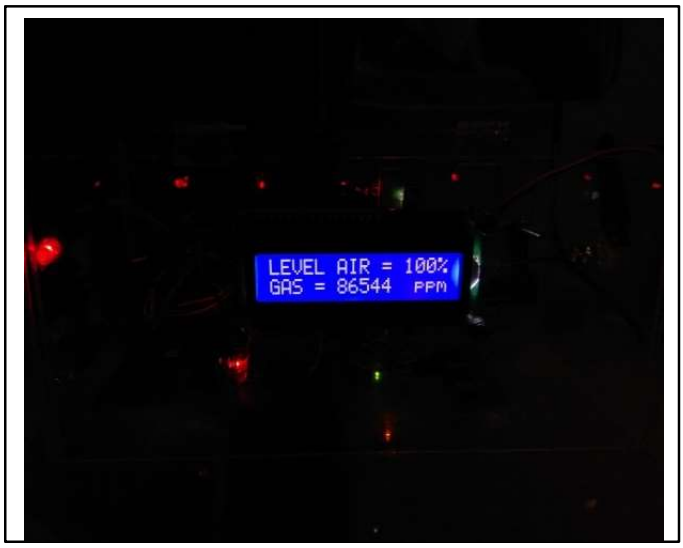

Fig. 12. 100\% Water Level

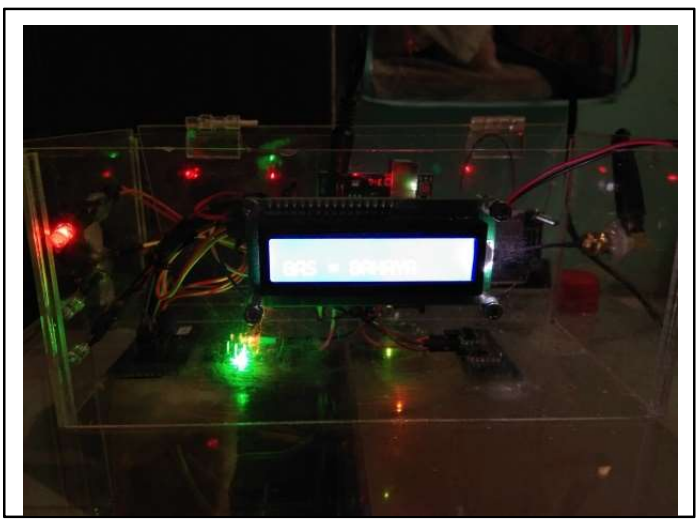

Fig. 13. LCD and Gas Display

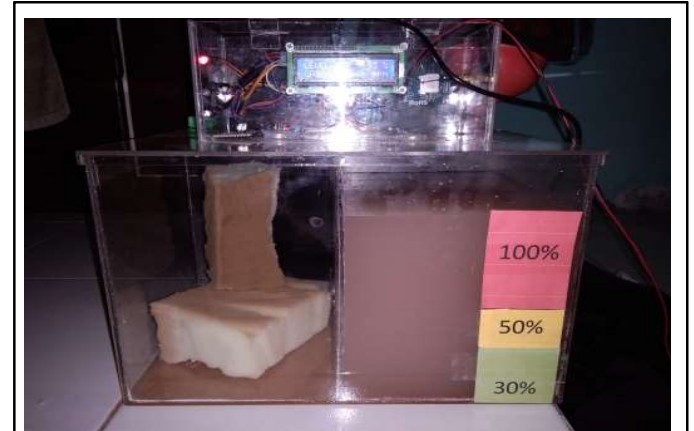

Fig. 14. LCD Display and Gas Hazard Detection 


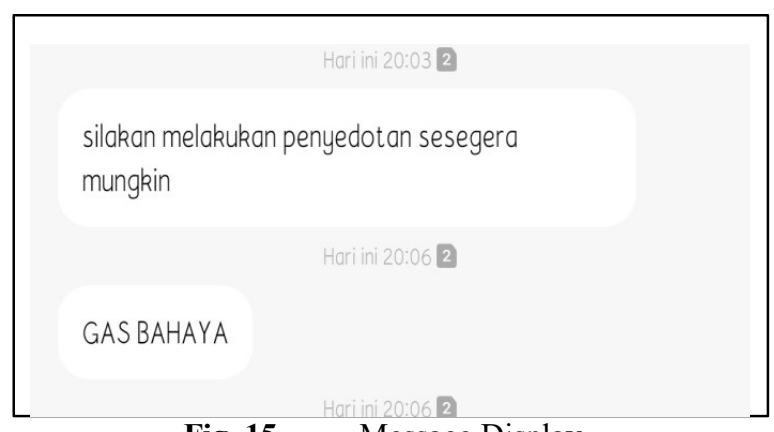

Fig. 15. Message Display

In the Fig. 12 shows that the water level in the septic tank is at a height of $100 \%$ automatically the results obtained directly appear on the LCD screem can be seen in Fig.13 which is the result of measurements from ultrasonic sensors. At an altitude of $100 \%$ it turms put that there is a detected gas content of $86544 \mathrm{ppm}$, the MQ-2 sensor automatically detects that the gas in a dangerous septic tank can be seen in Fig.14. data will automatically be sent to the smartphone in the form of the message " Please extract as soon as possible" and the message form of the gas that was detected as dangerous "Gas Hazard" the two results can be seen in Fig.15. then the results of the 100\% success test can ryn and the results obtained as expected.

\section{Conclusion}

In this research the ultrasonic sensor is able to read a height of $2 \mathrm{~cm}$ to $4 \mathrm{~m}$. because the device designed is only a prototype, the septic tank is designed with a height of $20 \mathrm{~cm}$. based on tests carried out by measuring the tank water level from a height of $31 \%, 50 \%$ to $100 \%$ and measuring the highest gas content in the tank, the results obtained are as desired. In general this tool runs well starting from Arduino which processes data, SIM800L sends messages, sensors detect and measure tank height.

[1] D. M. Wisesa, "Perencanaan Instalasi Pengolahan Air Limbah di Rumah Susun Tanah Merah Surabaya.” Institut Teknologi Sepuluh Nopember, 2016.

[2] H. S. I. Pertiwi, M. Rahardjo, and N. Nurjazuli, "Hubungan Pengetahuan, Sikap BAB, dan Kepemilikan Septic Tank Dengan Status ODF (Open Defecation Free) di Kecamatan Candisari Kota Semarang," J. Kesehat. Masy., vol. 6, no. 6, pp. 143-149, 2018.

[3] Mochamad Fajar Wicaksono, Aplikasi Arduino dan Sensor : Disertai 32 Proyek Sensor dan 5 Proyek Robot. Bandung: Informatika Bandung, 2019.

[4] D. Setiawan, J. E. Candra, and C. E. Suharyanto, "Perancangan Sistem Pengontrol Keamanan Rumah Dengan Smart CCTV Menggunakan Arduino Berbasis Telegram," InfoTekJar J. Nas. Inform. dan Teknol. Jar., vol. 4, no. 1, pp. 185-190, 2019.

[5] P. D. P. Adi and R. Arifuddin, "Design Of Tsunami Detector Based Sort Message Service Using Arduino and SIM900A to GSM/GPRS Module," JEEMECS (Journal Electr. Eng. Mechatron. Comput. Sci., vol. 1, no. 1, pp. 1-4, 2018.

[6] F. Saftari, "Proyek Robotik Keren dengan Arduino,” Jakarta Elex Media Komputindo, 2015.

[7] S. Sadi and I. S. Putra, "Rancang Bangun Monitoring Ketinggian Air dan Sistem Kontrol pada Pintu Air Berbasis Arduino dan SMS Gateway,” J. Tek, vol. 7, no. 1, pp. 77-91, 2018. 